\title{
Viral Breakthrough
}

National Cancer Institute

\section{Source}

National Cancer Institute. Viral Breakthrough. NCI Thesaurus. Code C120599.

The subject becomes viremic during the treatment period after a period of treatmentinduced aviremia or has an increase in viral load from nadir above a predetermined threshold during the treatment period. 